\title{
COMPREHENSIVE APPROACH IN THE FULL SPECTRUM OF CONFLICT
}

\author{
Aurelian RAȚIU \\ "Nicolae Bălcescu" Land Forces Academy, Sibiu, Romania \\ ratiu.aurelian@armyacademy.ro
}

\begin{abstract}
The present paper identifies relevant issues and challenges connected to the comprehensive approach/holistic approach in the full spectrum of conflict. The Comprehensive Approach (CA) concept implemented by NATO, EU, UN and even state actors is to satisfy the need for proactive engagement, to foster cooperation, coordination and contribution of all actors, before and during a confrontation or crisis. Conflictuality management requires good governance, economic development, rule of law and local ownership, all this in addition to military security.
\end{abstract}

Keywords: comprehensive approach, holistic, integration, spectrum of conflict, operational environment.

\section{Introduction}

The spectrum of conflict is a background for all military actions and operations, describing the environment in which military forces/structures take place. The main characteristic/main element for defining the spectrum of conflicts is the level of violence, ranging from peaceful interaction among international actors (states, corporations, international organizations, non-governmental organizations, etc.) to major combat operations/general war. Military forces operate throughout this spectrum.

However, the levels of violence do not always represent clear distinctions. Military operations do not necessarily go through a progression in either direction. Operations typically start somewhere along the middle of the spectrum, not at either end. Also, there may be different levels of conflict in different parts of a single Theatre of Operations, or even within an Area of Operations (AOO). Indeed, the levels may change over time within a single area. In addition, different actors may view their actions as being in different parts of the spectrum. What may be general war for one faction may be viewed as something else by another faction. For example, in 1993, in Mogadishu for Somali warlords was a Major Combat, instead for to the coalition forces was a Peace Support Campaign and later turned into a Counter-Insurgency (COIN). In general, no specific operation exists at just one point of this spectrum. In reality, a theatre of operations is more complex: at any one time there may be an intense fighting between combat forces in one place, insurgency and COIN in another and humanitarian operations, all within the same area of operations.

\section{Predominant campaign themes}

According to the Allied Joint Doctrine for Land Operations, there are 4 major domains/areas for certain limited intervention operations to be conducted throughout the spectrum of conflict. The 4 major areas, as shown in figure 1, are: 
a. Peacetime Military Engagement (PME);

b. Peace Support (PS); c. Security (in other previous documents it was Counter-Insurgency, but, operations to enable stabilization, including counter insurgency);

d. Major Combat.

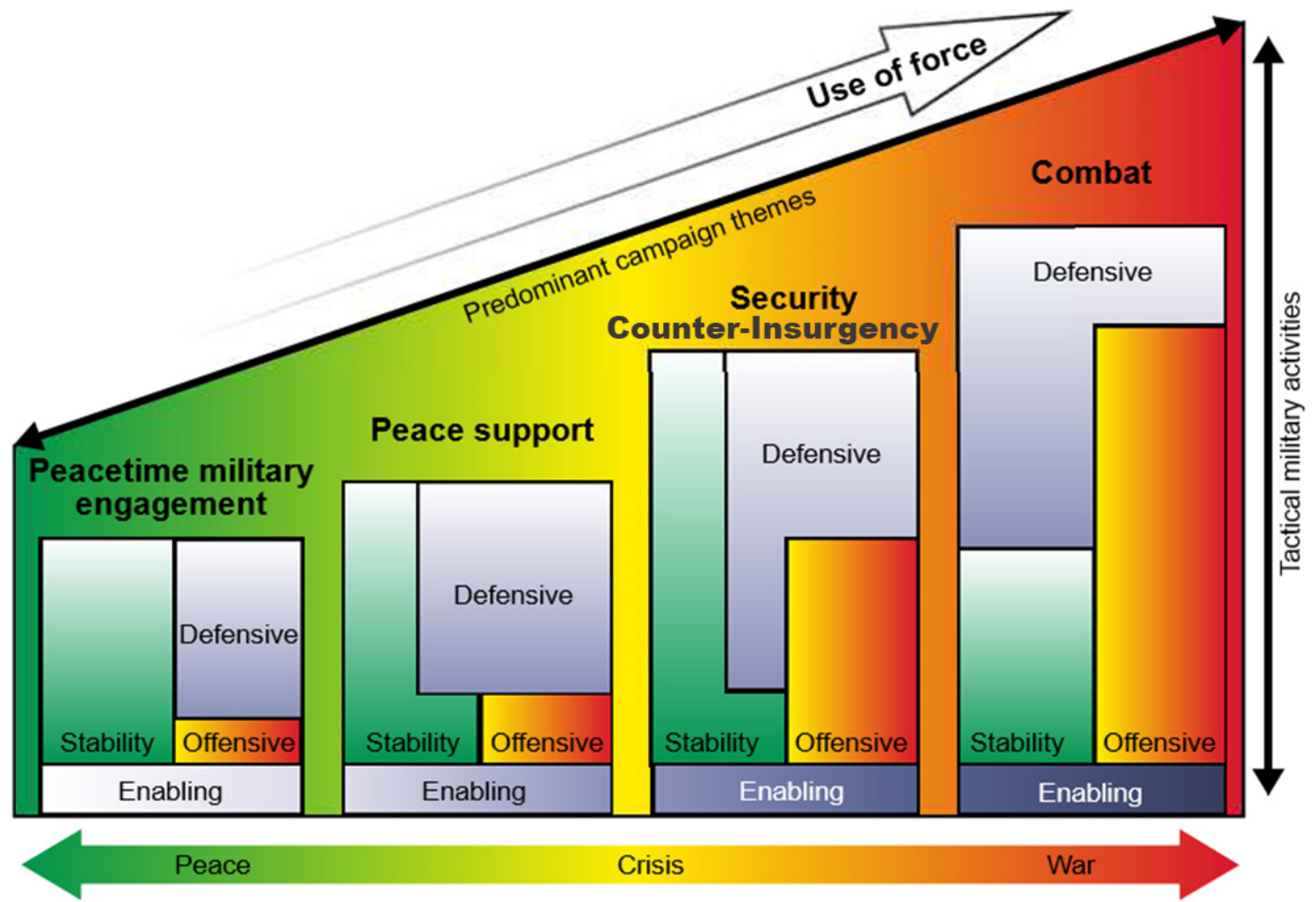

Figure 1: The Spectrum of Conflict [1]
The situation without violence or with low intensity of violence is at the left end of the spectrum, where a stable peace situation can occur. In this situation military forces can be engaged in peacetime (Peacetime Military Engagement). The activities of the actors are limited to peaceful interaction in politics, economics, humanitarian etc. (may include peaceful competition, cooperation, and assistance). The military's role is Peacetime Military Engagement designed to reinforce peaceful interactions deter the emergence of conflict and prepare for the successful resolution of conflict, should it arise. Peacetime Military Engagement encompasses military activities that include programs and exercises in order to improve mutual understanding with other countries and increase interoperability with treaty partners or potential coalition partners.
Activities within Peacetime Military Engagement are usually long term and have the lowest levels of risk attached to them. They are aimed at encouraging stability. Typical measures of their effectiveness include security sector reform and military support to reconstruction and humanitarian assistance. Combat is not provided, although there is always the possibility of terrorism against deployed forces.

Moving along the spectrum, a stable peace may degenerate into a condition of unstable peace, where two or more groups/factions threaten or use force to obtain their expected goals. In some cases, force may be applied by outside powers to limit the conflict. Military operations here are dominated by Peace Support. The objective is to prevent escalation of violence, reduce 
tension among competing factions and return to peaceful interaction.

Peace Support campaigns are usually mandated by the United Nations (UN) and may be directed/coordinated by other international organizations (IO), like: NATO, European Union (EU), Organization for Security and Cooperation in Europe (OSCE). In order to be successful, Peace Support Operations (PSO) requires a balance of military and non-military instruments. Also, these types of operations are mostly dependent on the support of the local population/local leaders, on the cooperation of the parties of the conflict with the other international actors and on the assistance of the international public opinion. The role of armed forces in peace support operations is, paradigmatically speaking, to create a secure and stable environment, providing specialized military support, to afford governmental agencies, non-governmental organizations (NGOs) to approach the causes of the crisis/confrontation and encourage a stable peace. Combat operations are usually rare in peace support campaigns, although there may be limited periods of combat, only in a Peace Enforcement Operation- one type of PSO.

Continuing along the spectrum, unstable peace may turn into an insurgency (which may include widespread terrorism), a condition to continue the conflict including significant intra-state or inter-state violence, but short of large-scale actions/operations by conventional forces. Security supposes operations to enable stabilization, including counter-insurgency as probably the most demanding situation. Activities conducted within a COIN campaign theme aim to defeat an insurgency through integration of military, paramilitary (police forces, local militias etc.), political, economic, psychological and civil actions. Military operations here are characterized by counter-insurgency (COIN), where the objective is to reduce the level of conflict to one that can be managed/controlled by executing a peace support campaign (through the application of force) and the support to building of a stable infrastructure (through reconstruction activities). Typical measures of improving counter-insurgency are those that decrease the number of violent incidents and increase the level of popular support for the local government and for the international forces.

The other end of the spectrum from peaceful interaction is general war, where the major military activity is major combat operations. Major combat operations can be characterized by the prevalence of combatfighting as major joint multinational operations at high levels of military art, also, by high rates of sustained combat activity, high resources consumption, and potentially high casualty rates. The goal of major combat is to defeat an enemy through offensive and defensive activities and reduce the level of conflict to smaller and then continue to reduce the level of violence towards peaceful interaction.

As a conclusion, in all types of operations, in all spectra of conflict, but especially in Military Support Operations and CounterInsurgency Operations involve many military and non-military aspects (political, social, economic), which, certainly, implies the implementation of a Comprehensive Approach (CA). These issues underline the need for a comprehensive approach .

\section{The actors in the operational environment}

The complexity of the operational environment, alongside the multitude and diversity of missions for the military, also supposes the presence in the theaters of operations of a large number of involved actors.

These actors may very well have a significant influence on the successful outcome of the campaign. This wide range of actors "cannot be simply divided into classifications of friend or foe. Indeed, many will shift from one classification to another during the campaign. Instead, these 
actors will sit along a range of positions in relation to their support of the campaign"[2]. For example, unknown or neutral/independent actors.

Some actors in the environment will be unknown in terms of their support for the campaign. These actors (particularly those who are indigenous to the operational environment) will support the campaign if they consider the objectives and end states, and the means to achieve them, as legitimate or if they support their own agendas. Their perception of legitimacy will depend on their culture and societal expectations.

In addition, some actors or entities within the operational environment will operate completely independently from military forces, even if their final goals are the same with campaign objectives. Such groups will avoid interaction with military forces and seek distance from allied forces. In this respect, military leaders must be aware of any such organizations within their areas of operation and how they may affect the outcome of the mission.

The environment relating to a Military Support or Counter-Insurgency campaign will be more than just a military battlefield. Desired final objectives will often require contributions from a variety of other actors: civilian agencies, non-governmental organizations, partner nations and other non-NATO nations' resources and forces. Therefore, we have to understand how to facilitate such integration, how to facilitate Comprehensive Approach.

Achieving the desired objectives must be understood across the force during the planning and conduct of operations. Leaders at all levels must build and foster a shared comprehensive understanding/a holistic view of the operational environment.

In the war time or in any other point along the spectrum of conflict, the land environment is unique in that it is where people live. Land operations have to deal with this complexity of an environment characterized by the presence of people and their infrastructure. Crises, which need Peace Support Operations or the insurgencies with COIN are characterized by complex combinations of historical, political, military, social, religious, cultural and economic issues. Therefore, the operational environment has to evaluate through political, military, economic, social, informational and infrastructural aspects.

Due to the complexity of the operational environment and the presence of multiple actors and agencies, along all spectra of conflict, it is recommended to achieve the objectives through a Comprehensive Approach.

\section{Comprehensive Approach (CA) - different perspectives}

Comprehensiveness means "to address the range of threats and challenges by the full menu of instruments in order to contribute to overall stability and security"[3]. Nowadays, in the security field, there is a general understanding that $\mathrm{CA}$ implies an integration the "political, security, development, rule of law, human rights, and humanitarian dimensions of missions and operations"[4].

However, the implementation of the concept at the level of the states or international organizations, there is no single common understanding of the essentials of a comprehensive approach

The United Nations refers to the comprehensive approach through Integrated Approach concept. In the vision of this organization an Integrated Missions is a "specific type of UN mission in which there are processes, mechanisms and structures in place that generate and sustain a common strategic objective and a comprehensive operational approach among the political, security, development, human rights and humanitarian actors at international and national level'[5]. From UN perspective an Integrated Approach requires: "a shared vision of the UN's 
strategic objectives, an integrated planning, a set of agreed results, deadlines and responsibilities for the delivery of tasks critical to consolidating peace, finally, agreed mechanisms for monitoring and evaluation"[6].

The European Union, like other actors in the field of Peacetime Military Engagement and Security (crisis management) in the spectrum of conflict, has been struggling with the challenge of how to generate coherence in civil-military actions. First of all, the EU "has developed its concept Crisis Coordination Arrangements(CCA), which refers to internal EU processes, both civil-military processes within the European Security and Defence Policy (ESDP)"[7]. Second step was defining Civil-Military Coordination concept (CMCO) which represents a coherence of tasks of Union's entities related to planning and implementing crisis management missions, an optimal interrelation of all capabilities such as effective cooperation with external actors. Civil-Military Coordination cannot be confused to CivilMilitary Cooperation - CIMIC. Civilmilitary cooperation can be considered as particular dimension of Civil-Military Coordination, applicable through interaction between EU civil-military instruments and other actors in the theatre of operations, achieved on the basis of operational plans. Civil-Military Coordination is at political and strategic level and Civil-Military Cooperation is at operational and tactical level.

NATO cannot alone manage the complexity of the risks and challenges of the security and operational environment. There is a great range of actors within the theater of operations or the operations area, who will be involved in, or will influence, the conduct of military operations. As the land environment tends to be where the people are, it is a particular challenge in land operations to interact with this wide range of actors - some of them are working for alliance forces and others against alliance aims.

According to the NATO Strategic Concept endorsed at Lisbon Summit 2010, shows clearly that a "comprehensive political, civilian and military approach is necessary"[8], and the need to implement a comprehensive approach is visible not only in military conflicts, in combat, but also in NATO's efforts to solve crises and 21st century security challenges such as: fight against terrorist organizations, improvement of energy security, the prevention of arms race and dangerous materials (chemical, biological, radiological and nuclear materials), defense against cyber-attacks. NATO's perpetual efforts in planning field providing the idea of a common aim and solutions, clear strategies and objectives direction before taking action, and an integrated planning to support nation' members contributions to the success of the mission.

Romanian perspective in the comprehensive approach domain. The Romanian National Defense Strategy for the period 2015-2019 reflects the need to promote an extended national security concept. The strategy has an "integrative and multidimensional approach"[9] in which the national defense combines a number of other dimensions: public order, intelligence, counterintelligence and security, diplomacy, crisis management, education, health and demography. As a consequence, these issues require a comprehensive approach. This document highlights that the interinstitutional response to crisis situations, becomes even more important if we refer to the interoperability capacity. In the White Paper of Defense, is stated that the future military conflicts or crisis management missions will be more complex and multidimensional, therefore, a holistic approach (comprehensive) of all power instrument is to be considered a success, which engages "political, military, diplomatic, informational, civil and economical instruments from various 
actors: state, governmental and nongovernmental organizations"[10]. The Military Strategy of Romania defines the strategic and operational principles and concepts that describe how armed forces are committed to achieving the set goals, and in this context they will involve significant relationship with "other agencies and government departments, international organizations (IOs), and NGOs, the host nation and other interested actors (media, local businesses, etc.)"[11].

As a conclusion, Comprehensive approach is a process of identifying and interpreting all the interests that occur in an operating environment to solve crisis and/or conflict situations. This approach allows for a more credible engagement of civil-military capabilities and offers the possibility of accurately determining the effects of the tridimensional environment (troopspopulation-opponent) in which the population element creates contexts difficult to predict.

\section{Conclusion.}

Given the diversity of situations, from all initiatives, decisions, documents studied, several strongly recommendations can be highlighted for more coherent, comprehensive approach:

- Configure the right partners and capabilities for the right mission at the right time. NATO needs to be able to connect very good with other actors, adding an emphasis on planning and a clear allocation of responsibility.

- Civilian expertise to be included in NATO planning, closer cooperation with international organizations and NGOs and NATO's increased connectivity with the wider world. Civilian actors should be able to benefit from cooperating with NATO.
- The actors should not see each other as competitors but being mutually bonded and complementary. As one way to achieve better unity of effort, co-location of civilian and military actors was suggested. At all events, there is a need for greater interaction and cooperation.

- The critical job of the military is to provide security for other actors to contribute and also to be able to provide military support for civilian efforts, when needed. There is a need for flexibility to adapt to the context and for critical success depends on dialogue, better communication and mutual understanding.

- A change of mindset should come first, then the technical arrangements to support the approach. Accordingly, there is a need to invest in cultural awareness in a cultural of comprehensive approach.

Consequently, no entity is capable of carrying out all tasks required on its own. NATO is responding to this by suggesting a closer cooperation amongst the responders of the international community and a more inclusive understanding of the situation

A culture of comprehensive approach plays the role of an ideology established to eliminate conceptual and action barriers between vectors of the two fields. Civil and military instruments develop into coherent capabilities when coordination culture creates a task force mobility, which could finally lead to diffusing the differences between civil and military.

To sum up, a comprehensive approach is best understood as a mind-set aiming for synergy where all actors respond to a crisis, established through coordination of political, humanitarian, development, and security efforts.

\section{References}

[1] Allied Joint Publication, AJP-3.2 Allied Joint Doctrine for Land Operations, Published by the NATO Standardization Office, 2016, p. 1-7.

[2] Ibidem, p. 1-3. 
[3] Eric Dion, Synergy: A Theoretical Model of Canada'S Comprehensive Approach, Publisher iUniverse, Bloomington, USA, 2017, p. 186.

[4] Ibidem, p.186.

[5] Conin de Cedric, The United Nations and the Comprehensive Approach, Danish Institute for International Studies, Copenhagen, Denmark, 2008, p. 3.

[6] Ibidem, p. 11.

[7] Kristiina Rintakoski \& Mikko Autti (coord.), Comprehensive Approach. Trends, Challenges and Possibilities for Cooperation in Crisis Prevention and Management, Ministry of Defence, Helsinki, Finland, 2008, p. 13.

[8] NATO, Strategic Concept for the Defence and Security of the Members of the North Atlantic Treaty Organisation adopted by Heads of State and Government in Lisbon, November, 2010, 21st paragraph.

[9] Presidential Administration of Romania, Strategia Naţională de Apărare a Ţării pentru perioada 2015-2019, Bucharest, 2015, p. 5.

[10]The Government of Romania, Carta Albă a Apărării, Bucharest, 2015, pp. 30-31, online https://www.forter.ro/sites/default/files/.../carta_alba_apararii.pdf, accessed at 20.04.2018.

[11] Ministry of National Defense, Strategia Militară a României, chapter VI, Monitorul Oficial al României, no. 789, October 7, 2016. 